\title{
A tradição da vítima revisitada ${ }^{1}$ \\ The review of the tradition of the victim
}

\section{Gustavo Souza²}

\footnotetext{
Versão modificada do trabalho apresentado ao GT Estudos de Cinema, Fotografia e Audiovisual no XVIII Encontro Anual da Compós, realizado na Pontifícia Universidade Católica do Rio Grande do Sul em junho de 2019.

${ }^{2}$ Doutor em Ciências da Comunicação pela ECA/USP, mestre em Comunicação e Cultura pela ECO/UFRJ e graduado em Comunicação Social/Jornalismo pela UFPE. Professor do Programa de Pós-Graduação em Comunicação da Universidade Paulista. Coordenador do GT Estudos de Cinema, Fotografia e Audiovisual da Compós (2020-2021). Contato: gustavo03@uol.com.br
} 
Resumo: Em 1988, Brian Winston apresentou a discussão em torno da tradição da vítima no documentário, ao tomar como objetos a produção inglesa de 1930 e o cinema direto norte-americano para defender que os realizadores dessas escolas concebiam seus personagens apenas como vítimas. Para desdobrar essa discussão, este trabalho se concentra em documentários brasileiros que abordam situações traumáticas. Eles acionam a hipótese de que existem ao menos duas dimensões para a vitimização que se distanciam da ideia de vítima somente como marginal; bem como o reconhecimento de que a vitimização é uma produção das políticas de Estado.

Palavras-chave: documentário; trauma; vítima.

Abstract: In 1988, Brian Winston presented a discussion about the tradition of the victim in his documentary, analyzing the English production of 1930 and direct cinema of 1960 s to assert that filmmakers belonging to these cinema schools thought of their characters as victims only. This paper discusses this further focusing on contemporary documentaries about traumatic experiences. The results suggest the hypothesis that there are two conditions to victimization when the victim is not considered a mere outcast; and that victimization is produced by State policies.

Keywords: documentary; trauma; victim. 


\section{Introdução}

Em 1988, o professor da área de documentário Brian Winston publicou The tradition of the victim in griersonian documentary - texto que reflete sobre a transformação de personagens em vítimas, inicialmente, na produção documental inglesa da década de 1930. Embora o título sugira a concentração nos filmes realizados pela escola liderada por John Grierson, Winston também debate essa faceta no cinema direto, surgido nos Estados Unidos, na década de 1960. Ao eleger pessoas à margem como personagens de seus documentários, os diretores dessas duas vertentes ajudaram a construir a ideia de que a vítima da sociedade é também a vítima dos meios de comunicação e que, como resultado, muitos documentaristas invadiram a privacidade das pessoas que retrataram. Com esse aspecto como norte, Winston elabora um argumento que opera numa chave dual composta por liberdade de expressão (por parte do cineasta) versus o direito ao controle da representação (por parte do personagem), com peso maior para o primeiro aspecto.

Mais de trinta anos após a publicação desse texto, a produção de documentário, para além da Inglaterra e dos Estados Unidos, conheceu novos arranjos narrativos, discursivos e estéticos que instigam a continuidade desse debate. Neste texto, o foco se concentra na produção brasileira de documentários que se voltam para situações traumáticas - abordagens individuais e coletivas de vitimização, suas consequências e como elas são compartilhadas na esfera pública - a fim de perceber como a experiência do trauma permite desdobrar a discussão sobre a tradição da vítima.

Winston analisou duas vertentes do documentário com propostas narrativas, estéticas e ideológicas bastante definidas. Hoje, a produção documental brasileira é diversa e não obedece a regras tão estritas para a composição dos filmes. Na ausência de escolas ou modelos tão demarcados, a seleção dos filmes obedece ao critério da abordagem do trauma em duas dimensões: a individual e a coletiva. Sobre o primeiro aspecto, integram o corpus Estamira (Marcos Prado, 2004), cuja personagem que empresta título ao filme, após ser estuprada, desenvolve um quadro agudo de esquizofrenia que altera sua rotina e sua relação com a família; e Jogo de cena (Eduardo Coutinho, 2007), especialmente a história de Claudiléa, que perdeu o filho de 19 anos assassinado num assalto. Em relação à esfera coletiva do trauma, estão Atos dos homens (Kiko Goifman, 2006) e Branco sai, preto fica (Adirley Queirós, 2015), ambos, respectivamente, sobre ações policiais que resultaram na morte de 29 pessoas na Baixada Fluminense e que deixaram dois jovens deficientes (um na cadeira 
de rodas e outro que passou a usar uma perna mecânica), em Ceilândia, periferia de Brasília. Assim, para desdobrar a discussão sobre a tradição da vítima, pensamos ser mais produtivo concentrar as atenções em filmes que tornam público o sofrimento, pois a diversidade dos meios e processos de produção documental não está divorciada do apelo visual de experiências sociais que constante e consistentemente colocamnos frente à vítima, tornando possível uma aproximação com a dor e, de certa forma, encorajando-nos a sentir o que ela sente.

No entanto, não defendo que somente esses quatro filmes deem conta do problema apresentado pelo texto. Diversos documentários que também abordam experiências traumáticas poderiam integrar o corpus de modo a enriquecer o debate, mas a delimitação é necessária para que possa haver uma aproximação efetiva com as obras. Embora cada filme seja visto separadamente, há pontos de conexão entre eles, de modo que a análise de um fornece pontos a serem abordados na análise de outro. Assim, a performance é mais facilmente acessível em Jogo de cena, Estamira e Branco sai, preto fica, bem como a importância do testemunho é a matéria-prima para o debate em Atos dos homens e Jogo de cena. Performance e testemunho podem ser vistos como domínios em que se elaboram a experiência traumática, servindo, portanto, como operadores de análise. Estruturar a discussão em torno desses dois eixos trata-se de uma escolha deliberada frente à ausência dessas questões na discussão original sobre a tradição da vítima. Quando justapostos, esses tópicos sinalizam para a hipótese de que existem ao menos duas dimensões para a vitimização, que se distanciam da ideia de vítima unicamente como marginal, assim como o reconhecimento de que ela não existe per se, mas que também é uma produção das políticas de Estado.

\section{A tradição da vítima}

Antes de me concentrar nos filmes, é importante oferecer mais detalhes sobre o que Brian Winston define como tradição da vítima. Seu ponto de partida, como apontado acima, é a Escola Inglesa da década de 1930, que fundou as bases narrativas e estéticas do documentário, que consistiam, em linhas gerais, na abordagem de temas sociais como habitação, trabalho, educação, saúde e bem-estar, com a predominância de um tom expositivo marcado pela narração em voz over e pela mobilização de personagens apenas para ilustrar, grosso modo, o que era narrado. Tal vertente foi liderada por John Grierson, mas também contou com realizadores como Paul Rotha, Basil Wright, Harry Watt e Alberto Cavalcanti. 
O discurso que orientava a produção de filmes tomava o documentário como agente de transformação social. A observação dos documentários, no entanto, revela um distanciamento desse propósito. Shipyard (Paul Rotha, 1935), sobre o trabalho num estaleiro, induz que os trabalhadores ficariam desempregados ao término da construção de um navio, embora não haja falas que possam comprovar essa suposição, conforme identifica Winston (1988). Também dirigido por Rotha em 1935, Face of Britain foi o primeiro documentário sobre os bairros pobres do centro industrial, com uma narração que reforça a incapacidade da classe trabalhadora de gerir suas próprias vidas. Numa perspectiva semelhante a Face of Britain, observa Winston, está Works and jobs (Edgar Anstey, 1935), sobre um centro de cadastro para desempregados, realizado sob encomenda do Ministério do Trabalho.

Há duas grandes fontes de inspiração para o grupo de Grierson. A primeira delas é Robert Flaherty, especialmente pelo tratamento poético e heroicizado dispensado às pessoas anônimas, como se vê em Nanook, o esquimó ${ }^{3}$ (1922). A segunda é o cinema soviético pós-revolução de 1917, cuja influência se dá pelo uso do cinema como uma ferramenta para a educação das massas, acrescida de um viés propagandístico da ideologia vigente. O diagnóstico de Winston (1988) diz que o encontro dessas duas referências resultou em um conjunto de filmes em que o trabalhador passa da condição de herói, ciente do seu papel na transformação social, a um outro, de classe dependente do Estado. É nesse deslocamento que se dá a tradição da vítima. Para o autor, isso aconteceu porque, na prática, a Escola Inglesa estava distanciada do povo e mais preocupada em atender às demandas do Estado, responsável pelos recursos para a realização dos filmes.

O resultado das escolhas desses realizadores são personagens que não falavam por si mesmos, seus nomes não eram identificados ${ }^{4}$ e tampouco havia a consulta sobre suas representações. O indivíduo como ilustração do tema associado a questões sociais e à propaganda ${ }^{5}$ seria, portanto, a combinação necessária para consolidar o estatuto da vítima nessa produção documental, em que pese uma

\footnotetext{
$\overline{3}$ Documentário sobre uma comunidade inuit que vivia no polo norte. Nanook é o personagem principal, e toda a narrativa se desenrola a partir de suas práticas cotidianas, como a caça e a pesca.

${ }^{4}$ A exceção é Housingproblems (Edgar Anstey, Arthur Elton, 1935), que destoa dentre os filmes realizados na Escola Inglesa pelo fato de os personagens falarem diretamente para a câmera sobre os seus problemas, além de terem os seus nomes identificados.

${ }^{5}$ A Escola Inglesa era financiada pelo governo britânico. Disso decorre o caráter de propaganda de muitos dos documentários realizados.
} 
desigual relação entre "a liberdade de expressão do realizador e o cerceamento dos direitos dos protagonistas" (WINSTON, 1988, p. 35).

Além da Escola Inglesa, o cinema direto norte-americano da década de 1960 viria a reforçar a tradição. Embora Winston (1988) reconheça um interesse inicial desta vertente por pessoas públicas (os presidenciáveis de Primárias, de Robert Drew, lançado em 1960, por exemplo), o momento mais profícuo ocorreu quando o foco migrou para “os destituídos de poder” (WINSTON, 1988, p. 41). A tecnologia que favoreceu o desenvolvimento do cinema direto (câmeras mais leves e captação do som sincrônico) também intensificou, segundo Winston, a invasão de privacidade. Antes, com os equipamentos pesados e a dificuldade para captação de som, o grau de intrusão na vida das pessoas era menor. Ele desenvolve esse argumento a partir de Titicut follies (1967) e Hospital (1970), ambos de Frederick Wiseman. No primeiro, sobre um manicômio judiciário, os pacientes têm suas imagens e seu cotidiano revelados, mesmo estando alheios a tudo que se passa. Em Hospital, Winston considera problemática a sequência em que um jovem sob efeito de drogas vomita repetidamente durante um surto em que pensa que irá morrer. “O anônimo rapaz do Midwest que vomitou fortemente [...] vomita sempre que o filme é exibido. Caso ele seja exibido na comunidade onde vive agora, espera-se, como um cidadão estável, que ele nada possa fazer contra isso" (WINSTON, 1988, p. 46). Embora houvesse o consentimento por parte dos personagens (no caso de Titicut follies, tal consentimento foi dado pelo diretor do manincômio, pois, dos 72 pacientes vistos no filme, apenas 12 preencheram o formulário que autorizava o uso de imagem), o modo como foram mostrados - o jovem no hospital numa situação vulnerável e os doentes mentais sem consciência do que acontecia ao seu redor levantou o questionamento: apenas o consentimento é suficiente? Não haveria, por consequência, o risco do constrangimento?

Diante desse cenário, Winston (1988) reivindica a necessidade de se debater a questão da vítima na teorização sobre o documentário, uma vez que as discussões se concentraram em aspectos como "transparência e narratologia, a moralidade da mediação e a reconstituição, o desenvolvimento de estilo e os efeitos dos novos equipamentos"6 (WINSTON, 1988, p. 35). Para o autor, a vítima é o outro de classe, aquele que não exerce o poder. Como consequência, identifica-se a construção de uma representação enviesada, com o adensamento da invasão de privacidade pelo cinema-direto, facilitada pelo desenvolvimento tecnológico. É válido notar

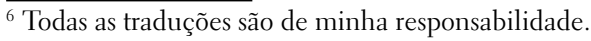


que essa mesma tecnologia também deu impulso às produções da "antropologia compartilhada” (WINSTON, 1988, p. 54), de Jean Rouch, que Winston defende como uma alternativa à tradição da vítima. A questão não pode ser vista apenas como consequência do aparato tecnológico, mas, especialmente, pelo uso que dele se faz. O enquadramento na categoria de vítima e a invasão de privacidade são, portanto, dois pontos que resumem a discussão apresentada pelo autor. A hipótese aqui adotada considera que é possível desdobrar a discussão para além dessas duas características ao verificar que há uma dimensão primária e uma secundária da vitimização, assim como um Estado produtor de vítimas.

\section{A vítima do trauma}

O conjunto de filmes que integra o corpus deste texto é marcado pela heterogeneidade tanto temática quanto estética. Enquanto Jogo de cena e Atos dos homens apostam no testemunho como um importante elemento de suas narrativas, Branco sai, preto fica flerta com a ficção científica, e Estamira sanciona a singular performance da protagonista. Porém há um ponto de convergência. Todas as situações abordadas por esses filmes podem ser lidas pela ótica do trauma: estupro (Estamira), chacina (Atos dos homens), violência que resulta em morte (Jogo de cena) ou em deficiência (Branco sai, preto fica). Conceito amplo e discutido por inúmeras áreas do conhecimento, o trauma pode ser definido como um acontecimento abrupto que deixa marcas indeléveis. A partir das pistas fornecidas pelos filmes, é possível recorrer à noção de trauma cultural (ALEXANDER, 2004; SMELSER, 2004), que, inserida numa abordagem sociológica, concebe o trauma como uma atribuição socialmente mediada: "um dano profundo, uma explicitação da violação de algum valor relevante, uma narrativa sobre um processo social terrivelmente destrutivo e uma demanda por reparação e reconstituição emocional, institucional e simbólica" (ALEXANDER, 2004, p. 11). Trata-se, portanto, de um sentimento difícil de assimilar e que interfere nas formações sociais e culturais de uma comunidade ou, como resume Smelser, "traumas culturais se criam como produto da história" (2004, p. 37). Essa perspectiva desloca o sujeito da condição de enfermo para a de vítima, sendo mais apropriada ao debate aqui proposto, muito embora se deva frisar que essa noção não descarta a dimensão individual do trauma, mas privilegia as emergentes propriedades coletivas das experiências traumáticas presentes no cotidiano.

O caso de Jogo de cena é elucidativo. Claudiléa relata a perda de um filho em decorrência de um assalto. $\mathrm{O}$ acontecimento, que desestrutura a família e a deixa com sérios problemas psíquicos, é individual, sem dúvida, mas está inserido numa 
lógica mais ampla - a do contexto de violência urbana que atravessa a sociedade brasileira. Este caso revela que uma rígida separação entre o individual e o coletivo pode mesmo ser útil para facilitar a análise das experiências traumáticas, mas, na prática, é até difícil de conceber.

Desse argumento, pode-se aventar que, se o trauma é diverso, as concepções de vítima também serão. O heterogêneo conjunto de filmes do corpus deste trabalho já sinaliza, de antemão, que é simplista considerar a vítima como mera receptora de efeitos psicológicos negativos existentes em diferentes níveis. Cabe, portanto, o entendimento do modo como o documentário, ao se debruçar sobre práticas cotidianas que produzem e reproduzem a vitimização, possibilita a discussão sobre quem adquire o rótulo de vítima, como isso se dá e suas possíveis consequências.

No entanto, nos três momentos aqui observados - década de 1930, década de 1960 e produção brasileira contemporânea - esse processo não ocorre da mesma maneira e, antes da análise dos filmes, é necessário abordar essas três temporalidades em perspectiva, para perceber como se constroem personagens como vítimas. Embora distintos em seus momentos históricos e em seus contextos de produção, uma aproximação entre essas vertentes revela que a noção de vítima está atravessada pela de povo; nos documentários da Escola Inglesa, a presença das classes trabalhadoras é significativa, e nos documentários da produção brasileira que integram o corpus deste trabalho, o outro de classe também ocupa um espaço importante. Podem-se ainda considerar os filmes do cinema-direto norte-americano que se voltaram aos anônimos. Tal aproximação induz a uma relação de alteridade em que se sobressaem as diferenças de classe e os lugares de poder que ocupam o documentarista e as pessoas por ele filmadas.

A observação dessa dinâmica revela, por outro lado, pontos de distanciamento, especialmente entre os documentários dos anos de 1930 e 1960 e a produção recente brasileira. A alteridade está presente nos três momentos, mas a relação estabelecida pelos cineastas com os seus personagens muda e, por consequência, mudam as representações. O documentário brasileiro contemporâneo aciona outros contornos para configurar o que se entende por vítima, quando cruza dinâmicas individuais e coletivas, valendo-se de diversificadas estratégias narrativas que não exclusivamente, mas com uma certa frequência, recorrem ao testemunho como um aliado na elaboração do trauma.

Nota-se o testemunho como uma importante ferramenta para relatar o trauma. À primeira vista, ele se refere à capacidade de presenciar, comprovar e sobreviver a um determinado evento. "O conceito de testemunho", 
aponta Seligmann-Silva, “desloca o 'real' para uma área de sombra: testemunha-se, via de regra, algo de excepcional e que exige um relato" (2003, p. 47), o que o torna “exemplar, não-fictício e profundamente marcado pela oralidade” (2005, p. 90). Segundo o autor, isso exige um mediador ou compilador para atribuir ao testemunho uma ordem lógica frente às possíveis lacunas e à falta de linearidade da narração. Embora sua reflexão se concentre na literatura, penso ser possível estendê-la às narrativas audiovisuais, como os documentários aqui em foco, que, como mediadores, organizam os testemunhos não somente para transmitir o terror da vida cotidiana, mas como uma forma de reparação simbólica para os que lidam com brutalidade e negligência.

Além de uma possível definição, a discussão deve contemplar aquilo que o compõe e o que ele aciona. Do formato talking head a sua instância apenas auditiva ${ }^{7}$, ele se conecta às questões em torno da vítima e aos processos de vitimização, podendo ser uma íntima manifestação do sobrevivente ou da testemunha, impulsionado por uma ruptura, uma crise ou uma desconexão que exigirá a elaboração de uma narrativa. Como recurso paradigmático no documentário, o testemunho se torna um ato de performance em que as pessoas refletem sobre suas próprias circunstâncias, num processo simultâneo de compartilhamento e de descoberta com alcances diversos. Como se verá adiante, por meio da performance, transmite-se a memória traumática que destaca a ausência de uns, assim como a presença de outros. O testemunho no documentário se dá por meio de falas, sons, pausas, gestos, hesitações, olhares, ou seja, elementos que demonstram a sua dimensão performativa e que remetem à possibilidade de tanto tecer uma narração a partir de experiências desestruturantes, atribuindo-lhe sentido e coerência, quanto de exprimir diferentes subjetividades marcadas pela dor. Perceber as implicações da natureza audiovisual da triangulação trauma, testemunho e performance é o que se pretende a partir de agora.

\section{Dimensão primária e secundária da vitimização}

Inicio a aproximação com os filmes por meio de Jogo de cena, documentário que tem como elemento central o testemunho. O filme de Eduardo Coutinho é composto apenas por depoimentos de mulheres que narram momentos de suas vidas que elas consideram importantes. O jogo que se vê no documentário alterna falas

\footnotetext{
${ }_{7}^{7}$ Nos documentários analisados neste trabalho, o testemunho ocorre de diversas maneiras: em Jogo de Cena, é comum encontrarmos talking heads (cabeças falantes), quando a pessoa é captada em plano americano ou close no rosto, já em Atos dos homens, o acesso ao testemunho se dá por meio da voz, pois muitos personagens não têm o seu rosto revelado.
} 
de mulheres que viveram as situações que narram com essas mesmas histórias sendo contadas por atrizes conhecidas do grande público (Andréa Beltrão, Fernanda Torres e Marília Pêra) e por atrizes pouco conhecidas. Como resultado, há, por exemplo, uma única história narrada por duas pessoas, o que prontamente abala a ideia do documentário como um lugar de acesso à verdade. Tal “jogo” não será priorizado por esse trabalho, mas é importante mencioná-lo porque dele se desdobram as relações entre performance e testemunho, foco da análise a seguir. Embora o diretor não tenha sugerido um tema às personagens, predominam as histórias de perdas - de pessoas, de relações. Aqui, concentro-me em Claudiléa, que narra a perda do filho numa tentativa de assalto.

Inicialmente ela descreve sua família para, em seguida, abordar o abandono por parte do marido, que, longe dela e de seus dois filhos, "resolveu curtir a própria vida”. Mesmo assim, Claudiléa consegue se reerguer e ter uma vida tranquila. Porém tudo isso muda quando seu filho é assassinado durante um assalto. "Foi a pior parte da minha vida [...], meu filho tinha 19 anos, ele era lindo, a gente estava num momento tão feliz, tão bom. Eu agradecia a Deus todo dia da gente estar feliz e Deus fez isso. Eu me desesperei, foi uma coisa louca. Aí eu ficava perguntando a Deus por que ele fez isso, pra Deus ir lá e ressuscitar meu filho, mas ele não ressuscitou, não”. Ela passa a viver, então, um período de grande sofrimento, sem conseguir voltar para casa ou ver fotos do filho. Encontra certa paz depois de um sonho em que ele lhe pede que não sofra mais, pois está bem onde ele está.

Nesta fala, assim como em todas as outras de Jogo de cena, percebe-se um ritmo folhetinesco na narração, com apresentação dos personagens, conflito e resolução do conflito. Essa estrutura permite que, aos poucos, o espectador adentre o universo da personagem, que, com a proximidade do relato da morte do filho, vai demonstrando cada vez mais emoção. As opções de enquadramento também contribuem para essa proximidade, pois, à medida que a história vai se tornando mais tensa, prevalece o close up no rosto em vez do plano americano. Antes mesmo de chegar ao "clímax" de sua história, Claudiléa já está chorando e assim permanece até o final.

O modo como a história é narrada e as opções de enquadramento sinalizam para a importância da performance na transmissão da memória traumática (TAYLOR, 2013). Essa ideia servirá, portanto, como porta de acesso à discussão, pois permite a leitura de documentários com diferentes temas e enfoques, que convergem para a exposição de indivíduos assombrados pela dor. Como trauma, performance também é um conceito discutido por diversas áreas de conhecimento e, 
por esse motivo, partir das pistas fornecidas pelos filmes se torna uma alternativa. Logo, Jogo de cena aponta para a perspectiva que entende "a performance como um repositório compreensivo de saber e um poderoso veículo para a expressão da emoção" (SCHECHNER, 2013, p. 45). Para além das expressões artísticas (dança e teatro, especialmente), tal definição se concentra no agente da performance, ao admitir que há uma espécie de atuação nas práticas cotidianas que se repetem, o que faz o autor conceber a performance como comportamento restaurado. Esse ponto de vista contempla o pragmático e o subjetivo, o concreto e o abstrato, e, quando aproximado do documentário, permite que a relação entre documentarista e personagem seja vista com menos ingenuidade, como sugere Baltar, uma vez que a performance problematiza "as negociações nem sempre pacíficas entre uma instância e outra, bem como as implicações da representação da alteridade" (BALTAR, 2010, p. 218-219).

Por meio da performance de Claudiléia, é possível acessar o trauma e, como desdobramento, aproximar-se de uma subjetividade marcada pela dor da perda. Ela relata que, após a morte do filho, passou cinco anos quase em estado vegetativo, e que o suporte da filha foi fundamental para atravessar esse período. Embora a sua fala termine de forma resignada, ela ainda custa a entender "por que Deus fez isso". Se o estatuto da dúvida permeia o jogo proposto pelo documentário, ele compõe também o plano interno das histórias narradas. A única informação visual disponível é o seu rosto em close. Assim sendo, é preciso “ouvi-lo", pois ele amplifica o sofrimento, evidencia uma agonia e, ao mesmo tempo, explicita a banalidade da violência, o que permite adensar a discussão sobre as configurações da vitimização.

A relação entre performance e trauma merece continuidade e está presente em Estamira - documentário sobre uma mulher de aproximadamente 60 anos, que trabalha no lixão de Jardim Gramacho, no município de Duque de Caxias, região metropolitana do Rio de Janeiro. Nos primeiros momentos em que a câmera se aproxima da personagem, é evidente sua perturbação mental. Seu vocabulário é repleto de palavras e expressões por ela mesma criadas e que fazem todo sentido no seu universo. Se, no depoimento de Claudiléa, prevalece a dor da perda como um fator que molda a sua subjetividade, em Estamira o sentimento mais recorrente é a raiva. Explosiva, Estamira esbraveja e se revolta contra alguém que não sabemos ao certo de quem se trata, mas, por sua performance - gestos, tom de voz e vocabulário próprio - pode-se deduzir que se refira a Deus, a quem despreza e duvida da existência. Sua missão é "revelar a verdade", como diz em inúmeros momentos. Nesse caso, a performance da personagem permite o acesso ao seu modo de ser, mas não esclarece os motivos pelos quais ela se encontra nesse estado de perturbação mental. 
Quem dará algumas informações que ajudam a entender a condição de Estamira é a sua filha Carolina. Ela levanta a hipótese de que, após ser estuprada, a mãe tenha desenvolvido um quadro agudo de esquizofrenia que alterou de modo radical o seu comportamento. O trauma revelado pela filha se torna um aspecto importante da narrativa do documentário porque pode ser um auxílio para se acessar a performance acima descrita e nos põe em contato com uma subjetividade marcada pela perturbação. A humanidade do outro sob ameaça - materializada na violência contra a mulher - é capaz de estabelecer um vínculo com a alteridade e conduzir à identificação com a personagem.

Estamira é vítima direta dos traumas que vivenciou, mas a sua performance raivosa a afasta consideravelmente da vitimização aos moldes da Escola Inglesa. Ela não se vê como coitada, e o filme lhe confere força e poder ao associá-la a raios e trovões, como já observou Baltar (2010). Por meio de uma montagem que articula a performance de Estamira com personagens "explicadores”, o documentário opera um duplo movimento: revela que a vítima do trauma é capaz de construir, de elaborar e ter eloquência em seu discurso, assim como evita que a personagem seja reduzida ao estigma da marginalidade, como se fosse um outro-exótico.

A montagem também revela um modo gradual de aproximação à Estamira - característica também refletida na estética do filme. Na abertura, ela é captada de longe, caminhando em direção ao aterro sanitário onde trabalha. O plano é hiper aberto, de modo que ela quase se confunde com a paisagem, um aspecto que se intensifica ainda mais pelo uso do preto e branco na fotografia. À medida que o filme avança, a câmera está mais próxima de Estamira, os enquadramentos são mais fechados e o preto e branco cede lugar ao colorido. Quando ela revela, por exemplo, ser um trovão e ter capacidade de ver o que as pessoas comuns não podem, o plano imagético reforça sua fala com imagens de raios e tempestades. Esse procedimento, marcado pela busca de linguagem "em fase" com a personagem, facilita o acesso à sua performance.

Se, como acredita Schechner, a performance é veículo para a materialidade de experiências e saberes, as performances tão distintas de Jogo de cena e Estamira revelam diferentes desdobramentos dos traumas sofridos pelas personagens em questão. A performance no testemunho se torna um meio para exposição da memória traumática, desdobrando a discussão para o reconhecimento da dimensão primária e secundária da vítima. De modos diferentes, esses documentários problematizam a vitimização individual como uma experiência de classe e de gênero através da qual é possível ler tanto o trauma quanto a narrativa da vítima como instâncias socialmente circunscritas. 
A outra questão diz respeito à mudança de lente para ver o personagem marginalizado. Como observa Winston (1988), a tradição da vítima ocorre, em grande parte, quando os documentaristas enquadram as pessoas que vivem em situação de exclusão apenas no escaninho da marginalidade. Estamira, inversamente, esforça-se para desmontar a expectativa de que viver numa condição adversa implica inevitavelmente assumir a adversidade como modo de vida. Além da performance da personagem, vale lembrar a fala de sua filha Carolina, que não apenas informa os traumas sofridos pela mãe, mas constrói um discurso bastante afetivo sobre ela. Carolina tem consciência dos distúrbios mentais de Estamira, mas o modo como isso é narrado não destitui a mãe de importância nem de dignidade.

\section{O Estado como produtor de vítimas}

Os dois documentários discutidos até aqui abordam o trauma em sua dimensão individual. Para continuar o debate, é preciso agora voltar as atenções para o âmbito coletivo. Inicialmente, o filme que fornece os subsídios para a discussão é Branco sai, preto fica, de Adirley Queirós, fábula que faz uso de convenções do cinema de ficção científica para narrar uma história que integra a memória de um grupo de moradores de Ceilândia, periferia de Brasília. O documentário se concentra em três homens: Marquim, Sartana e Dimas Cravalanças. Uma ação truculenta da polícia, no baile black Quarentão, em 1986, deixou Marquim paralítico e fez Sartana perder uma das pernas após ser atropelado por policiais montados a cavalo. A frase que intitula o filme foi dita por um policial durante a operação. Como vingança, eles planejam lançar uma bomba sonora em Brasília e, para isso, contam com Dimas Cravalanças, que vem do futuro (2073) para ajudá-los.

O documentário se volta mais para o cotidiano de Marquim e Sartana em seu plano de vingança do que necessariamente para uma explicação objetiva do evento traumático. Há várias sequências que revelam como Marquim vive agora na cadeira de rodas, como faz para se deslocar, o relato das dificuldades para fazer fisioterapia no plano piloto; assim como Sartana se tornou um especialista na manutenção de pernas mecânicas que ajuda outros sujeitos que estão na mesma condição. O filme se concentra, portanto, em mostrar com detalhes as cicatrizes do trauma no cotidiano e no corpo dos personagens. Eles são pretos, deficientes e moradores de periferia. No entanto, existe uma recusa à vitimização, a reduzi-los apenas à condição marginal. O documentário induz à reflexão sobre quem se torna vítima e quem pode incorporar ou mesmo resistir a essa identidade, distanciando-se de uma leitura dos padrões de 
vitimização per se. Trata-se, em alguma medida, de expor as mazelas de um Estado que opera também como produtor de vítimas.

A abordagem de Branco sai, preto fica ocupa-se de uma dupla tarefa: lançar luz sobre as instituições e as relações estruturais que favorecem imagens específicas de vitimização à custa de outras, como as que reduzem as periferias a lugares exclusivos de violência; e chamar atenção para situações que, apesar de produzirem séria vitimização, não são designadas como tal. Essa abordagem reveste a tradição da vítima de uma dimensão que me parece mais grave que a invasão de privacidade, diagnosticada por Winston (1988) em sua análise do cinema direto: o reconhecimento e a crítica de que a constante produção de outros é utilizada para legitimar a violência por parte do Estado.

As primeiras informações sobre o Quarentão são dadas pelos personagens centrais, que relatam como ele era um importante espaço de sociabilidade num lugar onde os aparatos culturais são escassos. No desenrolar do filme, Dimas Cravalanças reúne uma série de fotos tiradas no baile. Num constante vai e vem entre o passado e o futuro ou, como aponta Mesquita, "entre passado real traumático e futuro “especulado”" (2015, p. 9), uma memória traumática se instaura com a ajuda dessas fotografias, contrapondo a alegria e a diversão das imagens à violência e às mutilações após a ação policial, de acordo com os testemunhos. Aqui, a transmissão da memória traumática requer a exposição do desconforto decorrente de toda disruptura provocada pela polícia, representante do Estado.

Esse efeito é consequência da diversidade narrativa anteriormente apontada como um dos motivos para atualizar a discussão em torno do estatuto da vítima a partir de experiências traumáticas. Tal diversidade não reside apenas no encontro, em um único filme, dos elementos narrativos da ficção científica e do documentário, mas está presente também nos atores sociais, que produzem relatos não sobre os outros, mas sobre experiências e vivências que lhes são próximas. Adirley Queirós, diretor do filme, é morador de Ceilândia, onde o documentário foi realizado. Esse aspecto ajuda a reconfigurar o papel que exercem e os lugares que ocupam os sujeitos cujas vidas são marcadas por traumas ao mesmo tempo individuais e coletivos, especialmente quando a invasão de privacidade cede espaço a uma dimensão fabulatória que põe uma lupa sobre a conflituosa relação entre as políticas de Estado e as pessoas a quem essas políticas se voltam.

A violência policial também é tema de outro documentário debatido neste texto. Atos dos homens trata de uma chacina encabeçada por policiais militares que resultou na morte de 29 pessoas nas cidades de Nova Iguaçu e Queimados, ambas na 
região metropolitana do Rio de Janeiro, no dia 31 de março de 2005. Segundo um representante da polícia que presta depoimento ao filme, um comandante mais rígido assumiu o posto da região, causando a insatisfação de um grupo de policiais, que resolveu se vingar na população. O objetivo inicial do diretor era fazer um filme sobre sobreviventes de massacres no Brasil. Um mês antes do início das filmagens ocorreu essa matança, fazendo Goifman desistir do primeiro projeto e se concentrar apenas nesse episódio.

O filme justapõe a fala de três grupos: parentes das vítimas, jornalistas e moradores das cidades onde a chacina ocorreu. Aqui, concentro-me no primeiro grupo, em que prevalece a força do testemunho. De seus parentes, ouvimos apenas a voz e, quando falam, para preservar suas identidades, o que se vê é uma tela branca. Desse modo, as atenções se voltam unicamente para o que se fala, reforçando a densidade dramática da narração numa espécie de performance auditiva.

Todo o episódio é reconstituído e analisado por pessoas que, de algum modo, têm relação com o fato. Uma mãe fala da expectativa de encontrar o filho ainda com vida: "vi meu filho caído no chão e não acreditei, cheguei perto e perguntei se ele estava ouvindo, sacudi, sacudi, para ver se ele ainda estava respirando, mas já era tarde [...] Ele tinha um sonho de fazer um curso de filmagem, não para filmar pessoas, mas a natureza. Era um rapaz bom em matemática e que sonhava em entrar para a Marinha”. O testemunho dessa mãe aponta novamente para a revisão da noção de vítima no documentário, pois revela, para além do aviltante resultado da ação policial, um filho autônomo e com projetos para o futuro, distanciando-se da ideia de que as classes menos favorecidas são incapazes de gerir as próprias vidas. Tal relato se aproxima do de Claudiléia, em Jogo de cena, em que se nota a vitimização em sua dimensão primária e secundária, pois quem fica precisa lidar com o sofrimento da perda.

Após um episódio traumático, a construção de uma narrativa nem sempre é fácil, geralmente evita-se retomar o passado, o que pode dificultar a elaboração da narração. Haverá momentos que permanecerão sem uma enunciação possível, mas a tentativa de construir uma história a partir deles, de vê-los não somente como um amontoado de estilhaços, mas como um testemunho capaz de atribuir um sentido a esses estilhaços é, em tais condições, uma abertura para o compromisso com a vida. Num filme em que não há imagens das vítimas, é no testemunho que elas ganham existência. Especialmente no caso reportado por Atos dos homens, que se distancia do tratamento genérico dispensado a acontecimentos como esse pelos meios de comunicação massivos. 
O testemunho tem sido um dos componentes fundamentais da produção documental contemporânea, por ser um espaço em que, a um só tempo, reconstitui-se a vida de alguém e se combatem pontos de vista engessados sobre pessoas e lugares, especialmente quando são abordadas as periferias. Em Atos dos homens, é por meio do testemunho que se tem acesso às histórias de vida das pessoas assassinadas - seus projetos para o futuro, suas relações, seu trabalho - e não somente a um número de mortos. Mas os testemunhos também apresentam problemas, questionam, cobram uma retratação. Como a performance, o testemunho se torna necessário não apenas para a transmissão da experiência traumática, mas também destaca a importância das demandas de reparação, principalmente quando o trauma é causado pelo Estado. Dito de outro modo, o testemunho é uma forma de expressão e de conhecimento atravessado por informação e emoção, cujo desdobramento é o alerta, a denúncia, o aprendizado. Nos documentários sobre traumas decorrentes de ações policiais criminosas, ele sublinha a dimensão política da vida, assim como o dever da política de preservá-la.

Assassinatos em números expressivos, como os abordados por esse documentário, impactam de um modo que a vitimização vai além da vítima direta, ao incluir aqueles que testemunham e experimentam atos de violência de modo indireto, sofrendo as consequências dos danos infligidos a outros. O documentário informa que a matança teve início na rodovia Presidente Dutra, que corta a cidade de Nova Iguaçu, na Baixada Fluminense. À beira da estrada, duas travestis foram mortas Sem ter também sua identidade revelada, a mãe de uma delas ressalta que, a partir de agora, sempre olhará com medo para um policial. "O caráter não está na roupa, porque se o caráter estivesse numa roupa, estaria numa farda”. Enfatizar a vítima num plano homogêneo e horizontal, ainda que de um ponto de vista compreensivo, como fizeram os realizadores da Escola Inglesa, é desconsiderar as especificidades dos processos de vitimização (entre eles, a desenvoltura de uma sobrevivência resoluta), concebendo os mais pobres apenas como uma "classe do corpo" (SOUZA, 2009, p. 398), o que naturaliza uma escala hierárquica em que a vida de uns vale mais que a de outros. Nesse ensejo, o testemunho é uma das expressões mais tenazes de um desejo de não apenas expurgar o trauma, mas de superar as adversidades para continuar vivendo numa sociedade acomodada com o intolerável.

$\overline{8}$ Trata-se de um sinônimo para o que o autor classifica de "ralé" brasileira. O termo é uma provocação à tendência politicamente correta que dominou a sociologia brasileira em suas inúmeras tentativas de entender a nossa constituição social e, como desdobramento desse objetivo, as classes menos favorecidas ou, simplesmente, a "ralé". 
Performance e testemunho invocam o sofrimento como um componente necessário à compreensão do nosso perene contexto de vitimização que, no término de Atos dos homens, o documentarista anuncia não se tratar de um caso isolado: "até a finalização do filme, nenhum parente das vítimas recebeu indenização. Onze policiais estão presos, aguardando julgamento. Dois meses após as filmagens, uma nova chacina aconteceu na Baixada Fluminense. Só o filme termina aqui".

\section{Conclusão}

Ponto de partida para a discussão apresentada neste trabalho, a reflexão inicial sobre a tradição da vítima sublinhou duas importantes questões: a vitimização em si e a invasão de privacidade. Isso não implica que a produção de documentários tenha extinguido por completo esses aspectos no âmbito da representação (ou apresentação, como preferem alguns), ao contrário, construções problemáticas continuam a existir. Porém, como o trabalho de Winston (1988) tem mais de 30 anos e se volta para o passado (décadas de 1930 e 1960), essa discussão merece continuidade ao privilegiar a produção contemporânea a partir do documentário brasileiro.

A resposta a essa inquietação estabelece, de saída, que as concepções de vítima não são homogêneas, pois o que o documentarista entende como vítima pode não coincidir com o modo como o personagem se vê. A questão, no entanto, não se limita ao ângulo para olhar o fenômeno, mas ao reconhecimento de que viver em condições adversas não implica acatar essa rotulagem de modo transparente e acrítico. Por meio do testemunho, observa-se a transmissão da memória traumática em diferentes performances e, como desdobramento, pode-se aventar uma expansão para a noção de vítima que evita ver o outro de classe como alguém desprovido de força, subjetividade e criatividade, um aspecto mais nítido em Estamira e Branco sai, preto fica; bem como assinala que a vítima não é somente quem sofre diretamente o dano, mas também quem precisa lidar com suas consequências, como se vê em Jogo de cena e Atos dos homens. Por isso, é importante ressaltar que existem ao menos duas dimensões para a vitimização - uma primária, outra secundária - porque isso lança luz para o entendimento do modo como as práticas cotidianas produzem e reproduzem a vitimização e para possíveis demandas de reparação.

A articulação entre performance e testemunho na transmissão da memória traumática abre um precedente para que se reconheça que a vítima não é produto apenas das escolhas dos documentaristas, mas também fruto das políticas de Estado, especialmente quando as atenções se voltam para as populações pretas e periféricas, como se vê em Atos dos homens e Branco sai, preto fica. Tal abordagem reveste a 
tradição da vítima de uma crítica ao aparelho estatal como árbitro - e também arbitrário - do destino das vítimas que produz. Por serem financiados pelo Estado, é provável que os filmes produzidos pela Escola Inglesa tenham se isentado dessa abordagem. Os estudos do trauma e da vitimização exigem também a atribuição da responsabilidade a quem causa o sofrimento. Os documentários aqui em foco, especialmente Atos dos homens e Branco sai, preto fica, de diferentes maneiras, revelam que esse agente é o Estado brasileiro. Para além da vitimização em si e da invasão de privacidade, eles demonstram que os acontecimentos nefastos a que seus personagens foram submetidos deixarão marcas indeléveis em suas consciências, moldando para sempre suas memórias e mudando suas subjetividades de modo radical e irrevogável.

\section{Referências Bibliográficas}

ALEXANDER, J. “Towards a theory of cultural trauma”. In: ALEXANDER, J. et al. (org.). Cultural trauma and collective identity. Berkeley: University of California Press, 2004. p. 1-30.

BALTAR, M. “Cotidianos em performance: Estamira encontra as mulheres de Jogo de cena”. In: MIGLIORIN, C. (org.). Ensaios no real: o documentário brasileiro hoje. Rio de Janeiro: Azougue, 2010. p. 217-234.

MESQUITA, C. Memória contra utopia: Branco sai, preto fica (Adirley Queirós, 2014). In: ENCONTRO ANUAL DA ASSOCIAÇÃO NACIONAL DOS PROGRAMAS DE PÓS-GRADUAÇÃO EM COMUNICAÇÃO, 24., 2015, Brasília. Anais [...]. Brasília: Compós, 2015. Disponível em: https://bityli.com/iGtPM. Acesso em: 07 dez. 2018

SCHECHNER, R. Performance studies: an introduction. 3. ed. Londres: Routledge, 2013.

SELIGMANN-SILVA, M. "Apresentando a questão: a literatura do trauma”. In: SELIGMANN-SILVA, M. (org.). História, memória, literatura: o testemunho na era das catástrofes. Campinas: Ed. Unicamp, 2003. p. 45-58.

SELIGMANN-SILVA, M. O local da diferença: ensaios sobre memória, arte, literatura e tradução. São Paulo: Editora 34, 2005.

SMELSER, N. J. "Psychological trauma and cultural trauma”. In: ALEXANDER, J. et al. (org.). Cultural trauma and collective identity. Berkeley: University of California Press, 2004. p. 31-59.

SOUZA, J. A ralé brasileira: como é como vive. Belo Horizonte: Editora UFMG, 2009. 
TAYLOR, D. O arquivo e o repertório: performance e memória cultural nas Américas. Belo Horizonte: Editora UFMG, 2013.

WINSTON, B. "The tradition of the victim in griersonian documentary". In: GROSS, L.; KATZ, J. S.; RUBY, J. (org.). Image ethics: the moral rights of subjects in photographs, film, and television. Oxford: Oxford University Press, 1988. p. 34-57.

\section{Referências audiovisuais}

ATOS dos homens. Kiko Goifman, Brasil, 2006.

BRANCO sai, preto fica. Adirley Queirós, Brasil, 2015.

ESTAMIRA. Marcos Prado, Brasil, 2004.

JOGO de cena. Eduardo Coutinho, Brasil, 2007.

submetido em: 22 ago. 2019 | aprovado em: 21 set. 2020 